\title{
CHANGES IN THE SUB-ANTARCTIC IN THE MODERN ERA OF SCIENCE AND ENVIRONMENTAL CONSCIOUSNESS
}

\author{
by Dominic A. Hodgson
}

(with two plates)

\begin{abstract}
Hodgson, D.A. 2009 (11:xii): Changes in the sub-Antarctic in the modern era of science and environmental consciousness. Papers and Proceedings of the Royal Society of Tasmania 143(2): 19-24. https://doi.org/10.26749/rstpp.143.1.19 ISSN 0080-4703. British Antarctic Survey, Natural Environment Research Council, High Cross, Madingley Road, Cambridge, CB3 $\bullet E T$, UK. Email: daho@bas.ac.uk

This paper defines the "Inodern era of science and environmental consciousness" both in a global sense and, more specifically, when applied to the sub-Antarctic archipelagos. It briefly describes some key changes occurring in the sub-Antarctic terrestrial biome including climate change and the introduction of non-indigenous species. Three case studies are presented that demonstrate how important these changes are in the context of long-term natural climate and environmental variability. Finally, the role of science and environmental consciousnesses in informing future management of the sub-Antarctic islands is considered.
\end{abstract}

Key Words: sub-Antarctic, climate change, non-indigenous species, palaeoecology, management.

\section{INTRODUCTION}

The "modern era of science" in the Antarctic and sub-Antarctic is relatively easy to define as a legacy of the International Geophysical Year (IGY 1958) when many of the first systematic long-term monitoring programs were initiated and permanent scientific facilities established. It marked a partial shift in effort from economic exploitation towards systematic data gathering and scientific research.

The "modern era of environmental consciousness" is, however, a more nebulous concept. For some it is interpreted as a developing awareness of the natural world over the past c. 140 years. This has been marked by a number of pivotal events: the creation of the World's first national park at Yellowstone in California in 1872, the publication of Rachel Carson's Silent Spring in 1962 (Carson 1962), the Vietnam war, Civil Rights, Peace, and Women's movements of the 1960s, the 1970s Earth Day and the growth of the green movement, the publication of James Lovelock's Gaia theory in 1972 (Lovelock 2000) and, in Tasmania, the campaigns against the damming of Lake Pedder, the 1982-83 blockades to prevent damming of the Franklin River and, both in Tasmania and elsewhere, ongoing campaigns for the application of democracy to old-growth forest management.

However, when considering the sub-Antarctic, the concept of a developing environmental consciousness is not simple to apply. Accounts of the earliest expeditions suggest that the perception of their participants was that nature was something to be feared and tamed. For example, Captain James Cook's crew variously described their discovery of South Georgia as follows: "It exceed(s) in wretchedness both Tierra del Fuego and Staten Land which places 'till I saw this, I thought might vie with any of the works of Providence in that particular" (Charles Clerke 1775 in Beaglehole 1961, and Headland 1984, p. 29 ); "It is ... of less value than the smallest farmstead in England" (Anders Sparrman 1775 in Headland 1984, p. 29); and "The very thought to live here for a year fills the whole Soul with horror and despair ... charity lets me hope that human nature was never thought so low by his Maker, as to be doomed to lead or rather languish out so miserable a life" (J.R. Forster in Headland 1984, p. 29).
Attitudes to iconic species such a King Penguins, Aptenodytes patagonicus J.F. Miller, 1778, were hardly more charitable. George Forster, on encountering the King Penguins in Possession Bay, South Georgia, in 1775 wrote: "these birds were so dull as hardly to waddle from us; we easily overtook them by running, and knocked them down with sticks" (Headland 1984, p. 28). On Kerguelen, Captain James Cook "... found the shore ... covered with penguins and other birds, and seals. These latter were ... so insensible of fear ... that we killed as many as we chose" (Cook 1777, 24 December 1776). Even the early woodcuts by William Hodges, for example, of Possession Bay in Captain Cook's description of the island depict a dark and foreboding scene that is far removed from the images we see of South Georgia today (Cook 1777) (see pl. 1).

Historical context is critical in shaping these perceptions. One must not forget that a number of the sub-Antarctic islands were discovered by expeditions that had set out to find the "Terra Incognita Antarctica". Their excitement on finding land, then almost immediate disappointment on discovering it was just another island, no doubt coloured their perceptions. Added to this the deprivations experienced by expeditioners during sea voyages at that time must also be taken into account when comparing their perceptions with those of modern visitors who usually arrive in high levels of comfort and safety with at least some in a drug-induced stupor that has kept their sea sickness at bay.

By the time the islands were first systematically exploited, it can be argued that a new environmental consciousness was already well established, at least in Europe, where many of the early sealing and whaling companies were based. Here, the roots of the environmental movement had been developed by the Romantic poets: Wordsworth 1770-1850, Coleridge 1772-1834 and others who redefined nature as a thing of beauty and inspiration rather than something to be feared and tamed. At the same time many of the classical European parklands were being created by Capability Brown and his followers. However, the sealers, whalers and penguin renderers were practical men who, in all probability, did not perceive the islands through "romantic" eyes. Nevertheless, perceptions of the islands were changing; consciousness of the environment was that the islands represented new economic opportunities (to the extent that the early visitors 


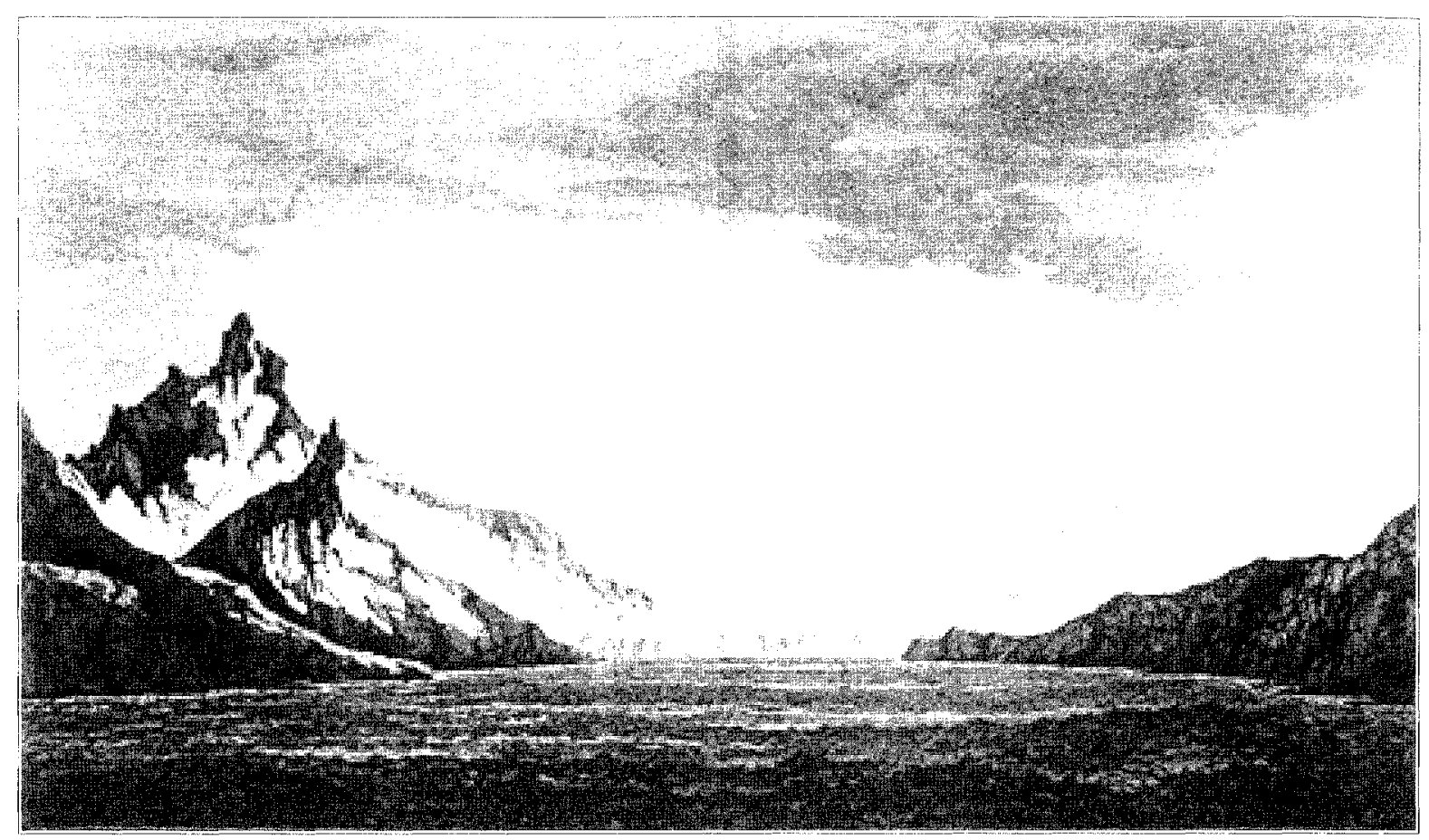

PLATE 1

Possession Bay in the Island of South Georgia, woodcut by William Hodges.

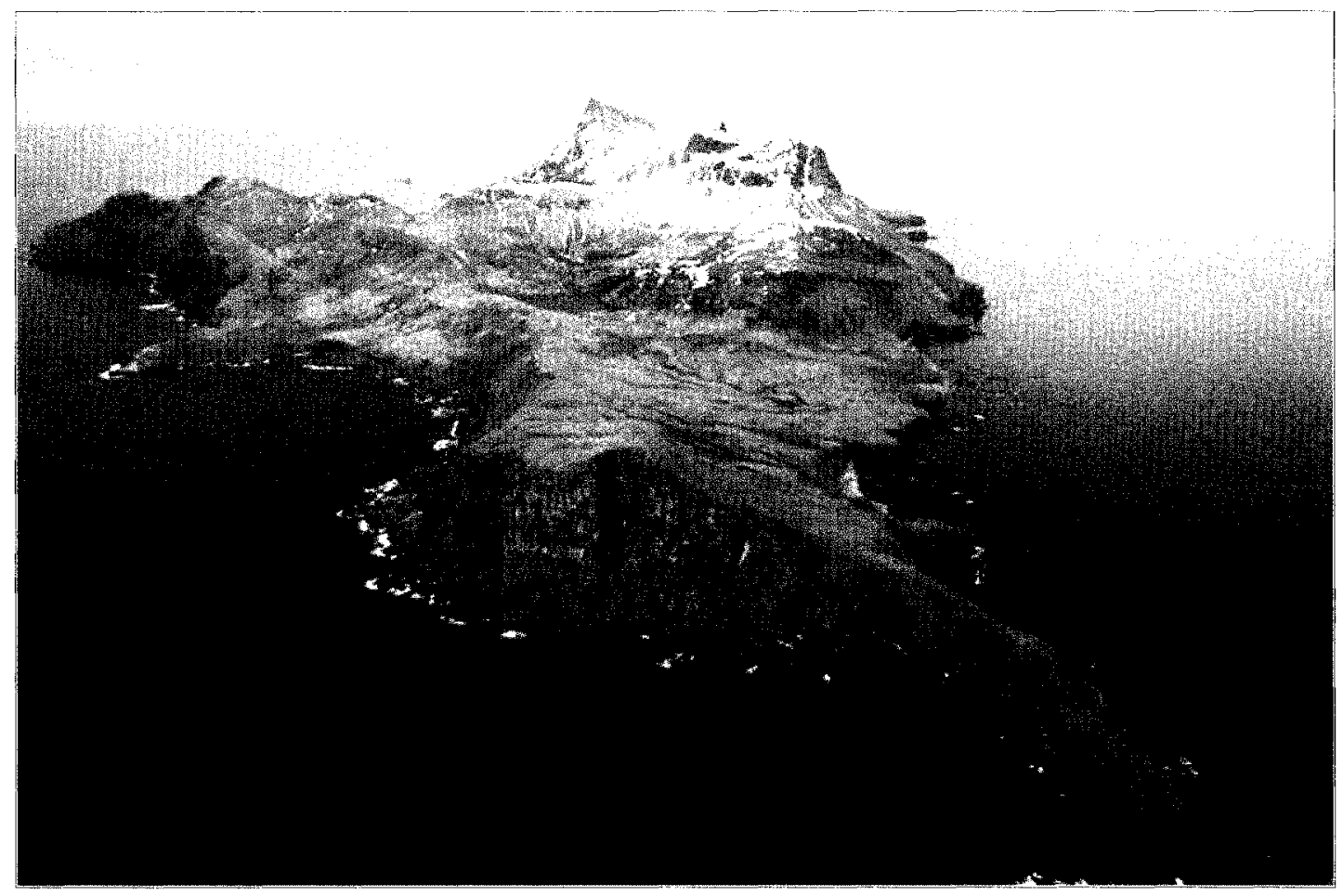

PLATE 2

Annenkov Island and Fan Lake. South Georgia can be seen on the top right of the photograph (courtesy of $K$. Schafer). 
rarely documented their voyages so that others couldn't share in the bounty). Several waves of exploitation ensued with many of the islands' whales, fur seals, elephant seals and penguins killed for fur and blubber, with some species being hunted to near extinction (Bergstrom \& Selkirk 2007). Here, poisons were applied for the first time, not to remove non-indigenous species (NIS) as occurs today, but to remove native wildlife that was interfering with the penguin oil industry. A. Hamilton at Macquarie Island notes in his 1894 diary that: "sailing about overhead were numbers of ... skua the terror of all other birds. The working party find them so destructive to the young penguins that, by means of poison, a very large number have been killed to protect the oil interest" (Hamilton 1894, p. 571). Thus, at this time environmental consciousness was centred primarily on identifying and exploiting the economic opportunities of the newly discovered islands.

Today's visitors (both tourists and scientists) clearly see the sub-Antarctic in a different way to these early pioneers, preconditioned as they are by a diet of television documentaries. For others, such as fishermen and tourism operators, the islands still represent their economic livelihood so, just as their predecessors exploited the blubber and oil, they respectively exploit the sub-Antarctic for its fish and to provide visitors with access to its natural attractions. What most visitors have in common is that they now perceive that there are threats to the natural environment. Two of the most important threats are climate change and the introduction of NIS (Bergstrom \& Selkirk 2007).

\section{CLIMATE CHANGE}

With the establishment of meteorological stations on many sub-Antarctic islands, climate change is relatively easy to measure. Despite the ongoing need for a robust databank of quality-controlled sub-Antarctic meteorological data (Pendlebury \& Barnes-Keoghan 2007), it is possible to calculate trends in the longer records with some confidence. For example, surface air temperature trends for Marion and Gough islands have risen at a rate of +2.8 and $+0.4^{\circ} \mathrm{C}$ per 100 years respectively (Jacka et al. 2004). These temperature trends are broadly consistent with positive sea surface temperature trends in the sub-Antarctic region (Pendlebury \& BarnesKeoghan 2007). There is also variation in the months when this warming is experienced; for example, at Marion Island warming has been experienced in all months except June (Pendlebury \& Barnes-Keoghan 2007), and on Macquarie Island, warming is most pronounced in late summer and early autumn, although the island cools during severe ENSO events (Frenot et al. 2005).

Other parameters such as precipitation have also changed. For example, at Marion Island annual precipitation has decreased since the mid-1960s, with the 1990s being the driest of the five decades that precipitation has been measured at the island (Smith 2002). Inter-annual variability in annual total sunshine hours is also large, and irregular, but a significant proportion of that variability can be ascribed to an average increase of 3.3 hours each year between 1951 and 1999 (Smith 2002, Stern 2009). A recent synopsis of climate change in the sub-Antarctic (Pendlebury \& Barnes-Keoghan 2007) identifies some of the climate projections through the twenty-first century including warming across the region and a decline in precipitation extending southwards towards $50^{\circ} \mathrm{S}$ over much of the sub-Antarctic, though these trends are still likely to show considerable variation at a sub-regional scale. These climate changes are predicted to have major changes on the biology of the sub-Antarctic (Bergstrom \& Selkirk 2007, Convey 2006, Convey et al. 2006, Frenot et al. 2005, Smith 2007).

\section{NON-INDIGENOUS SPECIES}

The threat of NIS involves both the existing consequences of NIS already established on the islands and the consequences of the introduction and establishment of new ones (Frenot $e t$ al. 2005, Smith 2007). Numbers of NIS are often difficult to determine, but often their impacts are relatively easy to measure. NIS were often introduced as a way of keeping a ready store of food in the event of forced stays on the islands (European Rabbits, Oryctolagus cuniculus (Linnaeus, 1758), Reindeer, Rangifer tarandus Linnaeus, 1758, Cattle, Bos taurus, Linnaeus, 1758, Pigs, Sus scrofa Linnaeus, 1758, to make the islands feel more like home or control other pests (Domestic Cats, Felis catus Linnaeus, 1758), and accidentally through ships' cargo movements and shipwrecks (rodents). Sometimes even the exact date of introduction is known. For example, on 22 October 1874 naval officer Cyril Corbet, part of an expedition that set out to observe the transit of Venus at Îles Kerguelen ( $49^{\circ} 20^{\prime} \mathrm{S}$ ), stopped at Robben Island (near Cape Town) to collect 150 European Rabbits and on arrival at Kerguelen, noted in his diary that: "a hole being dug in the hill-side, the bottom of the box was knocked out, and the poor little things left to burrow if they liked; but I'm afraid they have not a chance against these molyhawks and these other sea birds that also live in holes in the ground" (Corbet 1875 , p. 60). History has proved him quite wrong in this prediction! The impacts of NIS, including humans, are widespread in the sub-Antarctic. These impacts have been recently reviewed by Bergstrom \& Selkirk (2007), Smith (2007) and Convey (2008).

\section{ASSESSING THE IMPACTS OF CLIMATE CHANGE AND NIS}

Although the impacts of climate change and NIS are considered tangible threats to the sub-Antarctic terrestrial biome, it is important to judge their impacts within the context of long-term natural variability.

In order to define natural variability it is usually necessary to look beyond the instrumental measurements that began during the IGY (and occasionally before). Here geomorphological evidence and palaeoecological records can provide an invaluable longer term perspective, although it remains a challenge to provide unequivocal baseline descriptions of "unmodified" sub-Antarctic ecosystems, in either the marine or terrestrial realms. Such studies show that there are considerable variations in the impacts of climate change and NIS on different islands. For example, that there are islands where no change (outside of the range of natural variability) has occurred, islands where the combined impact of climate change and NIS are more significant than either in isolation, and other islands where recent impacts of NIS likely exceed all measures of natural ecological variability on millennial timescales. Examples of these progressive degrees of impact are described below.

An example of an island that has experienced few or no detectable recent impacts from climate change and NIS is 
Annenkov Island, just off the south coast of South Georgia (pl. 2). Here, a $5 \mathrm{~m}$ lake sediment core has been drilled into 18 m-deep Fan Lake and analysed for its sedimentology and biological fossils for a period spanning more than 7850 years (Hodgson unpubl. data). What is remarkable about this record is the absence of any floristic changes in the diatom communities (which are sensitive indicators of environmental change) in the past 200 years that are outside of the range of natural variability. Annenkov Island, like a number of the smaller offshore islands in the sub-Antarctic archipelagos, has remained, to the best of our knowledge, free of NIS and to date the reconstructions of its past environments suggest that it has not yet experienced any measurable ecological effects from recent directional climate change. However, like other islands in the South Georgia archipelago, the island it not immune to sporadic visits and indirect human activities, and, like other islands, is subject to the adverse effects of long-line fishing practices which are responsible for the rapid decline in some albatross populations. The first monitoring of these populations has been carried out on Annenkov Island and other islands in the South Georgia archipelago (e.g., Poncet et al. 2006), and future surveys will be able to establish if any systematic changes are taking place.

An example of an island which is currently experiencing the combined impacts of both NIS and climate change is the mainland of South Georgia. High-latitude glaciers are known to respond to climate changes, with the majority retreating at times of increasing temperature (A.J. Cook et al. 2005). Recent measurements on South Georgia from historical aerial photography and satellite data show that of over 100 coastal glaciers on South Georgia 97\% have retreated from the $1950 \mathrm{~s}$ to the present and that the rate of retreat is accelerating (A. Cook unpubl. data). But how significant is this? Multi-beam bathymetric surveys of the topography of the seabed around South Georgia show that in the past glaciers have extended as far as the edge of the continental shelf more than $50 \mathrm{~km}$ offshore occupying substantial glacial troughs to the north and south of the island (Graham et al. 2008). In the context of these substantial historical changes the oscillations of the past few decades would appear to be relatively minor. Moreover, the indigenous flora would appear to be well adapted to glacial expansions and contractions with many elements surviving through the glacial cycles (Van der Putten 2008). What is different now is that the introduction of NIS on the island, particularly Norway Rats (Brown Rats), Rattus norvegicus (Berkenhout, 1769), has made the implications of these glacial changes potentially catastrophic for some elements of the biota. Why? We know from observations that the presence of rats has decimated some populations of birds including the South Georgia Pipit, Anthus antarcticus Cabanis, 1884, which is endemic to the South Georgia archipelago. Here, the remaining tidewater glaciers extend into the sea and protect the remaining population of $\mathrm{c}$. $3000-4000$ pairs in a few mainland areas, the rest being confined to c. 20 small, rat-free offshore islands and islets $(<10 \%$ of total habitat). For this and other ground-nesting and burrowing birds the glaciers afford essential protection to the mainland populations whilst the offshore islands provide a final refuge (A. Cook unpubl, data).

What the measurements of accelerating rates of glacial retreat tell us is that soon, many of these tidewater glaciers will retreat up their feeder valleys and there will be no impediment to the rats (and other species such a Reindeer and House Mice, Mus musculus Linnaeus, 1758) occupying the few remaining parts of the island that are not currently impacted, leading to the degradation of the mainland native flora and fauna (A. Cook unpubl. data). Thus, the accelerating retreat of the glaciers, which on its own would have had a negligible, if not positive, impact on the island's wildlife, is now set to be the catalyst for further destruction. In this case the combined impacts of climate change and NIS will have a far greater impact than either factor in isolation.

A final example again concerns NIS, but in this case their distribution has remained unchecked by natural barriers. Macquarie Island, halfway between Australia and Antarctica, was discovered in 1810. As with many other sub-Antarctic islands, rodents invaded the island from ships' cargo movements and shipwrecks. Cats were then introduced to keep the rodents under control; European Rabbits were then added to give shipwrecked sailors and visitors something to eat. Until recently little has been known about the natural variability of the island's climate and vegetation prior to human arrival, so it has been difficult to assess the extent to which the recent impacts of these NIS compare with past natural environmental changes.

Palaeolimnological studies are being used to assess this. Sediment cores have been collected from lakes on the island, and when analysed will reveal to what extent the environmental changes taking place exceed those that might have occurred naturally. The first results suggest that the impacts of NIS might exceed all natural changes of the past few thousand years. For example, in one of the lakes studied, sedimentation rates have increased by two orders of magnitude in the past 200 years as a result of catchment slope instability presumably brought about by the burrowing and grazing activities of the rabbits. The dominant diatom species in the lake have also changed. Collectively this suggests that a regime shift has occurred in the lake ecosystem and lake catchment which is unprecedented in the Holocene (K. Saunders unpubl. data). Modern geomorphological mapping is also revealing the extent of the slope instability and erosion from the burrowing activities of NIS, and vegetation mapping is revealing the spatial pattern of vegetation change and the distribution of non-indigenous plant species (Bergstrom et al. 2009). Wildlife monitoring has documented the extinction of two endemic flightless birds, a rail and a parakeet, both extinctions attributed to humans and NIS. In this example of an island with no barriers to the distribution of NIS it appears that the impacts of NIS far outweigh any impacts that have occurred as a result of both millennial-scale and recent climate changes.

\section{THE IMPORTANCE OF THE SCIENTIFIC ERA}

In these three brief case studies, different degrees of intervention continue to be required if the islands are to be well managed in the future. Management plans are in place for most of the major sub-Antarctic islands and these are reviewed regularly. However, the objectives and principles of these management plans have yet to be more generally defined for the entire sub-Antarctic region on decadal to centennial time scales because, as shown above, these are influenced by the changing state of "environmental consciousness". This not only differs between individuals and the organisations and nations that they represent, but also has changed quite radically since less than a century ago. It is therefore 
possibly naive to think that a century from now they won't have changed quite substantially again. Fundamentally, it is not uniformly agreed for what the sub-Antarctic islands are being managed. Are they to be preserved, or conserved? How much economic exploitation is acceptable? What role should tourism play? Although most managers today would cite some form of conservation as their goal the answers to these questions differ subtly between management plans and unlike the Antarctic Treaty Area, are not underwritten by any single multilateral agreemenr.

These questions will continue to be debated. But what has changed since the IGY is that we now have scientific data to inform our management. Complementary long-term records archived in lake, terrestrial and marine sediments are now, on some islands, extending this instrumental record back thousands of years. Critically this means that many of the changes now taking place in the sub-Antarctic biome can be measured against pre-human impact status and long-term natural variability. It is apparent from these scientific data that islands such as Annenkov Island, Bird Island, Heard Island, Prince Edward Island, and some of the minor islands of the sub-Antarctic archipelagos are now the most appropriate places to meet preservation objectives, where the ancient biomes of the sub-Antarctic still, to a varied extent, survive. In December 2008 a team of researchers visited Prince Edward Island $20 \mathrm{~km}$ northeast of the much larger Mation Island for a week and "enjoyed noticing the abundance of spiders and caterpillars crawling through our tents and over our shoes, and the noise of burrowing birds calling all night. This does not occur on Marion Island due to the legacy of cats and mice" (Shaw 2009 , p.9). However, preservation aims must be tempered by the reality that all systems will change, with or without human intervention. Natural colonisation will occur and in the absence of agreed rules as to how to identify a NIS, it is hard to define what you do with them. For example, during the 2003-04 austral summer a single specimen of the plant Leptinella plumosa Hook.f. (Asteraceae) was reported having likely arrived via natural means with a seabird, or via human mediated dispersal on Heard Island, and this raises interesting ethical and management issues for the degree of intervention required and the ongoing management of the island (Turner et al. 2006).

Where conservation and remediation is the aim, for example on Macquarie Island, detailed vegetation mapping and wildlife surveys are now permitting thorough assessments of the response of the islands' flora and fauna to the ongoing NIS eradication programs (Bergstrom et al. 2009), and the dangers of unintended consequences. For example, on Macquarie Island vegetation mapping has identified enhanced damage by rabbits following the successful eradication of cats, demonstrating the complexity of managing islands with an NIS problem and the need for well-defined long-term objectives to be built into management plans. Palaeolimnological and palaeoecological studies will also enable the efficacy of these programs to be judged in the context of the longer term historical record, and benchmarked against natural baselines and natural variability. On South Georgia, satellite-based monitoring of the retreat of the tidewater glaciers has revealed the imminent danger of the rat population extending its range.

Where economic objectives exist, for example on islands such as South Georgia, the relentless exploitation of the penguin, seal and whaling stocks to the point of economic collapse has now been replaced by a fisheries management informed by scientific data gathering and including real time computer modelling of fish stocks and fishing effort. If this continues to be successfully applied, and illegal fishing brought under control, then a long-term sustainable fishery might result. Economic tourism is also being monitored to a limited extent with surveys and scientific data being gathered on impacts of visitors on vegetation and wildlife from which the overall potential impact of the industry could in principle be better managed. In all these examples the "modern era of science" has put managers in a position where they can chose to be well informed by objective data (Frenot et al. 2005, Tejedo et al. 2009, Tin et al. 2009).

\section{CONCLUSIONS}

When invited to present this paper my mandate was to discuss "changes in the sub-Antarctic in the modern era of science and environmental consciousness". I have shown that "environmental consciousness" is a difficult concept to define, and is different between individuals and organisations, and changes substantially over time. Although in some parts of Western society there has been a growing awareness of the need for environmental conservation since the mid-1800s this has generally been a view held by minorities. Until relatively recently, environmental consciousness has not been applied in a consistent way to the sub-Antarctic biome which has experienced successive waves of economic exploitation and, latterly, with the development of management plans, varied efforts at conservation and preservation. What can bedefined, though, is the "era of science". This has, particularly since the IGY, provided data that enable us, for the first time, to manage and exploit the islands with knowledge of their past variability, precise measurements of our direct and indirect impacts (climate change, NIS, economic exploitation) and informed forecasts of the nature and direction of future environmental changes. With this post-IGY legacy of science, the tools have been made available for the development and implementation of scientifically-informed management plans and an empirical route to good custodianship. It remains to be seen if we will use them.

\section{ACKNOWLEDGEMENTS}

This paper was presented at the Second International Forum on the sub-Antarctic held in Hobart on 26-27 April 2009. Pete Convey, Steve Roberts, Mieke Sterken, Elie Verleyen, Wim Vyverman, Alison Cook and Krystyna Saunders are acknowledged for their useful discussions and/or permission to cite their unpublished data. Patricia Selkirk, Patrick McBride and an anonymous reviewer are thanked for their helpful and constructive advice.

\section{REFERENCES}

Beaglehole, J.C. 1961: The Journal of Captain James Cook on his Voyage of Discovery. 2, The Voyage of the Resolution and Adventure 1772-1775. The Hakluyt Society, Cambridge: $1021 \mathrm{pp}$.

Bergstrom, D.M., Lucieer, A., Kiefer, K., Wasley, J., Belbin, L., Pedersen, T.K. \& Chown, S.L. 2009: Indirect effects of invasive species removal devastate World Heritage Island. Journal of Applied Ecology 46: 73-81 (doi: 10.1111/j.13652664.2008.01601.x). 
Bergstrom, D.M. \& Selkirk, P.M. 2007: Human impacts on SubAntarctic terrestrial environments. Papers and Proceedings of the Royal Society of Tasmania 141(1): 159-167.

Carson, R. 1962: Silent Spring. Houghton Miffin, Boston: 404 pp.

Convey, P. 2006: Antarctic climate change and its influence on terrestrial ecosystems. In Bergstrom, D.M., Convey, P. \& Huiskes, A.H.L. (eds) Trends in Antarctic Terrestrial and Limnetic Ecosystems: Antarctica as a Global Indicator. Kluwer Academic Publishers, Netherlands: 253-272.

Convey, P. 2008: Non-native species in Antarctic terrestrial and freshwater environments: Presence, sources, impacts and predictions. In Rogan-Finnemore, M. (ed.): Non-native Species in the Antartic. Gateway Antarctica Special Publication 0801: 97-130

Convey, P., Barnes, D.K.A., Clark, M.S., Hodgson, D.A. \& Peck, L.S. 2006: An holistic approach to understanding the biological impacts of climate change: Antarctica as a planetary warning system. Inside Agriculture 2: 16-39.

Cook, A.J., Fox, A.J., Vaughan, D.G. \& Ferrigno, J.G. 2005: Retreating glacier fronts on the Antarctic Peninsula over the past half-century. Science 308: 541-544.

Cook, J. 1777: A voyage towards the South Pole and round the World performed in HM Ships Resolution and Adventure in the years 1772-1775. Two Volumes. W. Strahan \& T. Cadelle, London: 378 and $396 \mathrm{pp}$.

Corbet, C. 1875: Venus at the Isle of Desolation: My Private Joumal During the Transit of Venus Expedition of 1874. Alfred Randle, Southampton: $48 \mathrm{pp}$.

Frenot, Y., Chown, S.L., Whinam, J., Selkirk, P.M., Convey, P., Skotnicki, M. \& Bergstrom, D.M. 2005: Biologica invasions in the Antarctic: extent, impacts and implications. Biological Reviews 80: 45-72.

Graham, A.G.C., Fretwell, P.T., Larter, R.D., Hodgson, D.A., Wilson, C.K., Tate, A.J. \& Morris, P. 2008: New bathymetric compilation highlights extensive paleo-ice sheet drainage on the continental shelf, South Georgia, sub-Antarctica. Geochemistry Geophysics Geosystems 9: Q07011, (doi:10.1029/2008GC001993).

Hamilton, A. 1894: Notes on a visit to Macquarie Island. Transactions of the New Zealand Institute 27: 559-579.

Headland, R.K. 1984: The Island of South Georgia. Cambridge University Press, Cambridge: 293 pp.

Jacka, T.H., Budd, W.F. \& Holder, A. 2004: A further assessment of surface temperature changes at stations in the Antarctic and Southern Ocean, 1949-2002. Annals of Glaciology 39: $331-338$.

Lovelock, J.E. 2000: Gaia A New Look at Life on Earth. Oxford University Press, Oxford: $176 \mathrm{pp}$.

Pendlebury, S.F. \& Barnes-Keoghan, I.P. 2007: Climate and climate change in the Sub-Antarctic. Papers and Proceedings of the Royal Society of Tasmania 141(1): 67-81.

Poncet, S., Robertson, G., Phillips, R.A., Lawton, K., Phalan, B., Trathan, P.N. \& Croxall, J.P. 2006: Status and distribution of wandering, black-browed and grey-headed albatrosses at South Georgia. Polar Biology 29: 772-781.

Shaw, J. 2009: Prince Edward Island Survey 2008. Scientife Committee for Antarctic Research, Evolution and Biodiversity in the Antarctic Newsletter 3: 9.

Smith, V.R. 2002: Climate Change in the Sub-Antarctic: An llustration from Marion Island. Climatic Change 52 : 345-357.

Smith, V.R. 2007: Terrestrial ecological processes and problems on Sub-Antarctic Islands. Papers and Proceedings of the Royal Society of Tasmania 141(1): 99-109.

Stern, H. 2009: Climate change in the sub-Antarctic: an illustration from Heard Island. 21st Conference on Climate Variability and Change, the 89th American Meteorological Society Annual Meeting. Phoenix, Arizona. Unpubl.

Tejedo, P., Justel, A., Benayas, J., Rico, E., Convey, P. \& Quesada, A. 2009: Soil trampling in an Antarctic Specially Protected Area: tools to assess levels of human impact. Antartic Science 21: 229-236.

Tin, T., Fleming, Z.L., Hughes, K.A., Ainley, D.G., Convey, P., Moreno, C.A., Pfeiffer, S., Scott, J. \& Snape, I. 2009: Impacts of local human activities on the Antarctic environment. Antarctic Science 21: 3-33.

Turner, P.A.M., Scott, J.J. and Rozefelds, A.C. 2006. Probable long distance dispersal of Leptinella plumosa Hook.f. to Heard Island: habitat, status and discussion of its arrival. Polar Biology 29: 160-168

Van der Putten, N.2008: Post-glacial palaeoecology and palacoclimatology in the sub-Antarctic. Unpublished $\mathrm{PhD}$ thesis, University of Ghent, Belgium. [name given as Van de Putten in text - pls check and correct]

(accepted 6 October 2009) 